\title{
Benjamin, Adorno and Modern-day Flânerie
}

Commenced circa 1927 and halted only by his sudden death in 1940, Walter Benjamin's Das Passagen-Werk (The Arcades Project) attempts to construct an alternative history of modernity centred around the urban developments of 19th-century Paris. Amongst the most significant images of Benjamin's version of metropolitan life is that of the flâneur. Benjamin's impression of the flâneur and the activity of flânerie - strolling and observing - is informed by the work of the poet Charles Baudelaire (1821-1867), whose volumes Les Fleurs du Mal (The Flowers of Evil) and Le Spleen de Paris (Paris Spleen) were unheralded in terms of language, style and the depictions of inner-city life contained therein. The urban wanderer of Baudelaire's Parisian scenes, closely-related to such marginal types as the collector, the rag-picker and the detective, in turn harks back to Edgar Allan Poe's short story 'The Man of the Crowd' (1840), which Baudelaire himself translated and where the outline of the flâneur first appeared (Benjamin, 1969: 168-169).

In contemporary terms, to speak of the flâneur is to call to mind a type who, post-Benjamin, has typically been glimpsed only in indistinct form: in philosopher Michel de Certeau's various tactics for individual autonomy, especially as espoused in the spatial practice of 'walking in the city' (1984); in Paul Auster's novel City of Glass (1985), where narrator/investigator Quinn tenaciously tracks the mysterious Stillman through the streets of New York; in Richard Sennett's vision of wandering through 'the humane city' in his The Conscience of the Eye (1990); in artist Matthew Buckingham's 2003 film installation A Man of the Crowd and 2005 slide projection One Side of Broadway; in the comic-tragic figure of French actor/director Jacques Tati's Hulot, who, in the classic trilogy of Les Vacances de M. Hulot (1953), Mon Oncle (1958) and Playtime (1967), confronts modernity with a flâneur- 
like mix of fascination and suspicion and encourages the same of the viewer. ${ }^{1}$ Just as the promeneur of 'the garden landscape [took] refuge in the shadow of cities' (Benjamin, 1999: 442) and emerged as the flâneur, so with the intensification of modernity the flâneur has been superseded by another figure, one of whom it might still be asked: what is he searching for? Benjamin underscores this prophetic aspect in Baudelaire's prototype, noting that his endeavours conceal 'behind a beneficent mirage the anxiety of the future inhabitants of our metropolises' (p. 21). To speak of the flâneur in the 21st-century is to attribute certain aspects or idiosyncrasies of flânerie to what must in reality be entirely new kind of urban nomad.

Here, my method of approaching the notion of modern-day flánerie will be to interweave the work of Walter Benjamin, whose intimate relationship with the modernity of his own past and present continues to provoke new ways of thinking about the future, with that of Theodor Adorno, whose special critical relationship with Benjamin has had such a profound influence on culture and aesthetics in the intervening decades.

As Stephen Zelnick puts it,

Benjamin never stopped imagining a messianic moment wherein the ruins of the past become a path to new illuminations. Modernist fragments can glow with significance, an incandescent hope. Adorno, in sharp contrast, pursued a ruthless negation of the cultural events of his world. For him, the popular arts were a new order of enslavement, the means by which the enslaved learn to love their captivity. (1985: 409)

Adorno and Benjamin have most often been treated as combatants, but it may be more constructive to explore the Adorno-Benjamin dialectic in a manner which suggests an underlying synthesis between the two. The principal tactic is to identify loopholes, ways in 
which individuals can and do assert themselves by operating against the dominant grain, standing out from the cultural crowd even as they become more immersed in it. By complementing the Benjamin of the Arcades period with Adorno's critical correspondences and his subsequent Negative Dialectics, it is possible to conceptualise an effective rendering of flánerie in the new century as an 'antidote to the fever of living in cities' (Patke, 2000: 13) and as a general remedy for other, acutely modern-day maladies.

\section{At the crossroads}

Written toward the end of his life, Walter Benjamin's final correspondences with his friend Theodor Adorno say much about their complex intellectual relationship, with both moving in essentially the same direction but on quite distinct paths. In a letter to Adorno dated 4 October 1938, appended to a portion of what he at that time refers to as 'the Baudelaire' (conceived as a chapter of the larger Arcades project), the impact of escalating political tensions in Europe upon Benjamin's scholarship - the reprehensible Munich agreement, handing a large part of Czechoslovakia to Nazi Germany, was signed only days earlier - can easily be detected:

Yesterday, I prepared the several hundred books I have here for shipment to Paris. Now, however, I am increasingly coming to feel that this destination will have to become a transfer point for them as well as for me: I do not know how long it will continue to be physically possible to breathe European air; after the events of the past weeks, it is spiritually impossible even now. This observation is not easy for me to make; but it simply cannot be avoided any longer. ${ }^{2}$ (p. 575)

Adorno responded from New York, having departed Europe for the United States some months earlier. Today, the reader obtains a clear sense of how crossing the Atlantic placed 
Adorno well and truly at the centre of what was, for him, a contemporaneously unfolding cultural crisis. Certainly his reply to Benjamin shows Adorno to be focused upon the matter at hand, namely criticism of the former's work on Baudelaire and in particular his methodological approach:

The basic reason for [my] disappointment is that ... the work represents not so much a model for the Arcades as a prelude to that project. Motifs are assembled but not developed. In your cover letter to Max [Horkheimer], you presented this as your express intention and there is no mistaking the ascetic discipline you allowed to rule, making it possible for you to abstain from conclusive theoretical answers to questions throughout the text and probably even making it possible for you to allow the questions themselves to become apparent only to initiates. But I ask myself whether this kind of asceticism can be sustained in the face of this subject and in a context that places such powerful internal demands on you. (p. 580)

Adorno's reaction at Benjamin's seeming refusal to buttress his project theoretically gets to the heart of the primary difference between their philosophical positions. In particular, it speaks of Adorno's ostensibly teleological attitude to modernism in contrast to the patchwork, non-linear appreciation inherent in Benjamin. Alongside this, the latter's outsider status, already heightened by his remaining in Europe and difficulties in establishing a formal association with the academy, ${ }^{3}$ is confirmed by the decision of Adorno and the Institute for Social Research (operating in exile out of Columbia University) not to make public, and thus place open to discussion, the texts Benjamin forwarded to them (Aesthetics and Politics ['Presentation III'], 2007: 104-105). ${ }^{4}$

As far as Adorno is concerned, his criticism of the paper on Baudelaire - much of which concerns the notion of flânerie - derives most notably from his own refined take on aesthetic 
modernism. That is, Adorno remains unflinching in his insistence upon certain 'principles of structuration' that form the basis of the (formalist) trajectory of modernism (Witkin, 2000: 148) most obviously represented in the twelve-tone music of composer Arnold Schoenberg. While for Benjamin flânerie is an activity through which new opportunities emerging at the interface of modernism and mass culture can be explored, Adorno condemns this kind of engagement with everyday life as futile behaviourism. Instead, he sought from Benjamin an interpretation that would 'do justice to Marxism' (Scholem and Adorno, 1994: 583). ${ }^{5}$ Thus Adorno finds that Benjamin's fragmented, dream-like interpretation of 19th-century Paris should reflect more explicitly the (to his mind) destructive nature of the historical bifurcation of modernity toward the diametrically opposed poles of modernism and mass culture. In a letter to Benjamin dated 10 November 1938, he says: 'Panorama and "trace," flâneur and arcades, modernism and the immutable without theoretical interpretation - is this "material" that can patiently wait for interpretation without being consumed by its own aura?' (Scholem and Adorno, 1994: 580) [original italics]. Benjamin's reply on 9 December in part shows him eager to argue that in the following chapter (not yet viewed by Adorno) he intends to provide the theoretical illumination absent from his writings thus far. Nonetheless, Benjamin would never become as astringent as Adorno in his evaluation of mass culture. On the face of things, Adorno's philosophy is informed by the inevitability of radical modernism's grand narrative - a utopian impulse leading inexorably toward a redemptive negative aesthetics. But this is only part of the story.

In his essay on Adorno, modernism and mass culture, Andreas Huyssen (2002) describes how resilient this well-honed dichotomy - between avant-garde and culture industry - has proved over the ensuing decades. ${ }^{6}$ Yet he goes on to emphasise not only how it represents an oversimplification of a complex debate, one in which the supposedly unconquerable divide 
between those two historical outcomes of modernity can no longer be sustained. Huyssen also shows that charges of elitism against Adorno, predicated upon his consistent critiques of the culture industry, conveniently ignore the numerous footholds for a positive, emancipatory cultural criticism present in much of his writing (pp. 51-52). For example, this standard dualism fails to differentiate, as Adorno did, between a constructive popular culture created by the populace and a homogenised mass culture that arises out of the apparatus of the culture industry.

Adorno's position is underpinned by his idea of negative dialectics, which updates the Hegelian notion of dialectical thought as a way of progressing beyond oppositional relationships in order to arrive at a more advanced, more rational level of understanding. At the heart of negative dialectics are the notions of immanent critique and identity thinking. Adorno is stridently opposed to versions of transcendental criticism embodying fundamental concepts that appear somehow to be beyond criticism - simply the way things are. He refers to such transcendent philosophy as 'the fallacy of constitutive subjectivity' (Adorno, 1973: $\mathrm{xx})$ : a falsely attained state of enlightened reason that is premised upon suspect foundations and essentially blind to the realities of totalitarian oppression (the culture industry being his preferred example of the latter phenomenon). An immanent critique contrasts this by '[remaining] within what it criticises' (Jarvis, 1998: 6), encouraging interpretations which are historically valid in that they emerge out of, rather than claim independence from, philosophical tradition (p. 151). At the same time, dialectical thinking must focus wholly upon the object itself, discarding extraneous associations that discourage independent understanding and lead toward assumptions of totality (identity thinking) for the corrective course of non-identification: 'criticising what an inevitable formalisation has made of the potential' (Adorno, 1973: 151) [my italics]. Non-identification in negative dialectics hence 
privileges ongoing analysis over the standard Hegelian concept of an outcome in which an evolution toward a final understanding is presupposed. For in Hegel's dialectics, Adorno believes, the outcome obtained when one equates two negatives (the dialectical problem) with a positive (the dialectical outcome) is not truthful to the process; rather, it is a mere illusion consistent with the logic of identity thinking (p. 158). In the final analysis Adorno's negative dialectics is posited not as a tangible solution to a problem but rather as a way of '[making] visible, as contradiction, the real antagonisms which are masked by philosophy's striving for logical identity' (Jarvis, 1998: 170) [original italics]. For Adorno, synthesis and equilibrium are replaced by perpetual and meticulous critique, a permanent revolution.

Negative dialectics may also be seen as an ongoing process of denial - denial of the possibility of revealing absolute truth or some other form of positive dialectical reconciliation. Both were, for Adorno, absurd goals in the wake of World War II and the Jewish holocaust: 'after Auschwitz, our feelings resist any claim of the positivity of existence as sanctimonious, as wronging the victims; they baulk at squeezing any kind of sense, however bleached, out of the victims' fate' (Adorno, 1973: 361). Undoubtedly exacerbating this negativity in Adorno's mind were the rapid expansion post-war of the culture industry (most obviously in the US, from where Adorno did not finally depart until 1953) and the Cold War political climate in which Stalinism (more or less an extension of Nazism under a Marxist rubric) prospered. The absolute critical obligation at the heart of negative dialectics must therefore be one of a constant self-reflection, lest thought be 'from the outset in the nature of the musical accompaniment with which the SS liked to drown out the screams of its victims' (p. 365). As Jarvis says, '[Negativity] cannot provide a blueprint for what the good life would be like, but only examines what our "damaged" life is like' (1998: 9). And any semblance of redemption in this irrevocably damaged life of modern-day commodity 
capitalism is to be located, according to Adorno, amidst the radically alternative aesthetics of high modernism; in the abstract painting of Wassily Kandinsky, the prose of Franz Kafka and Samuel Beckett and, most tellingly of all, the atonal music of the so-called second Viennese school of composers.

As Huyssen (2002) emphasises, there has been some discussion - most notably in Bürger (1984) - on the innate differences between the modernist and avant-garde aesthetics of the early 20th-century. Huyssen makes particular reference to the avant-garde doctrines of the Dadaist and Surrealist movements, both characterised by 'attempts to dissolve the boundaries between art and life' (2002: 42) through practices such as collage. Adorno's arch-modernism rejects any movement away from the autonomy of the art work. Such a conception of what is valid aesthetic practice seemingly leads to an even more drastic divide between high and mass culture: 'where high art itself is sucked into the maelstrom of commodification, modernism is born as a reaction and a defence' (p. 49). At the same time, however, Huyssen further unravels the intricacies of Adorno's vision by insisting that his unswerving disgust at the standardisation and pseudo-individualisation rife in commodity culture does not merely translate to a 'conservative defence of the high cultural canon' (p. 50). In the final analysis, Adorno is a 'critic of [both] 'high culture' and 'mass culture'” (Kellner, 2002: 86).

Yet so, despite their many disagreements, is Benjamin. Caught up in the midst of a postindustrial society evolving at an ever more rapid pace, the two stand together in 'tense solidarity' as advocates for 'a philosophy of history formed by experiences of modernity in aesthetics' (Wiggerhaus, 1994: 196). In concert with Adorno, though at the same time adopting a quite distinct methodology, Benjamin seeks to both understand and criticise the progress of modernity in a contemporary setting of great social and cultural crisis. And like 
Adorno, this is crucially reinforced by Hegelian philosophy. Though similarly concerned with the methodology of immanent critique, Benjamin is otherwise indebted, much to Adorno's dismay, to that aspect of Hegelian logic that allows him to 'scrupulously [eschew] explicit thematisation of the methodological premises underlying his work' (Wolin, 1982: 163). ${ }^{7}$ While Adorno always appears to be obsessively moving forward toward the advent of a profound high modernism, Benjamin is torn between a necessary (in Marxist terms) ideological condemnation of modernity and the joys and insights of burying oneself in the heart of the metropolis. As Marshall Berman says, 'he [Benjamin] cannot resist one last look down the boulevard or under the arcade; he wants to be saved, but not yet' (1983: 146).

Where Benjamin parts most significantly from his colleague is in his belief that an omnipresent mass culture might provide the best access point for any attempt to mobilise the populace for political ends. '[He] recognised, with some urgency, the need to extend the role of the intellectual in order to engage with the people and to do this through transforming the existing mass media while simultaneously making use of its technological advances' (McRobbie, 2005: 295). In other words, the democratic turn in the Arcades project and 'The Work of Art in the Age of Mechanical Reproduction' signifies an attempt to tackle the very same philosophical problem as Adorno - namely, undertaking a dialectical investigation of the modern condition - from below rather than above. The kinds of cultural productions criticised by Adorno around the time of his final correspondences with Benjamin were many and varied: jazz and popular music; photography; Hollywood movies. At the same time, some of these relatively new forms of artistic expression were being championed by Benjamin. To his mind, photography and film in particular lessened the distance between artist and audience, liberating both parties and enhancing art's political possibilities. Although this break with tradition is detrimental to the ritual nature of the aesthetic 
experience (travelling to attend the concert hall or art gallery; engaging 'one on one' with the celebrated object), it allows art to be accessed in more 'natural' circumstances such as the in the home (the phonographic record; the photographic reproduction) or local neighbourhood (the film house; the jazz club). Benjamin prophesises the future dominance of this kind of mass-consumption, along with the associated decline of the ritual value of the traditional artwork, in effect downplaying the concerns of Adorno regarding the isolation of high art in the face of mass entertainment.

Yet, as Susan Buck-Morrs puts it,

Benjamin's argument managed to tread on all ten of Adorno's intellectual toes ... aping the official line of the Communist Party, Benjamin was claiming that the art pour l'art which Adorno had judged positively as an alternative to mass culture was the aesthetic parallel to fascism. [At the same time] Adorno was startled by Benjamin's uncritical affirmation of film, the medium of mass culture which had taken the place of traditional, 'autonomous' art. (1977: 148-149)

Benjamin in many ways rejects Adorno's largely unambiguous approach to the problem of mass culture: there is no possibility of a straightforward answer for a man who, as Angela McRobbie points out, 'disputed the idea of progress, historically and philosophically' (2005: 304). For Benjamin, the traditional Marxist take on modernity and the prolongation of commodity capitalism leads ultimately to a dead end. He seeks a new way of thinking about mass culture that is sufficiently critical of the transformative processes of modernity yet neither inexorably deterministic nor ignorant of the possibility of genuine autonomy amongst the general population. 
Benjamin's expose on the flâneur, reflective of his own methodology, is in turn roundly criticised by Adorno. By sacrificing developed theory for the mere assemblage of images and 'objective reflection for the sake of political correctness' (Buck-Morrs, 1989: 228), Benjamin's subjectivism has, claims Adorno, led him to 'the crossroads of magic and positivism'; the latter then warns him (with characteristic eloquence) that '[the spot] is bewitched' (Scholem and Adorno, 1994: 582).

Ultimately, the unfolding political, humanitarian and cultural crises of the between-wars period underpin the critical concerns of both Adorno and Benjamin: it is their responses to the problem that differ so much in kind. Adorno associates himself squarely within the modernist narrative, where ever more rarefied and isolated artworks stand opposed to both totalitarianism and a burgeoning mass culture. In his view, both history and future can be revealed immanently in the aesthetic material of the modernist composition, a circumstance more or less limited, in music and literature, to the serialist techniques of Schoenberg and Berg and the anti-novels of Kafka and Beckett respectively. Benjamin's approach to modernism, on the other hand, is largely informed by the modernity of 19th-century Paris and by figures - such as the detective and the collector - who explore and embrace mass culture, defying the kind of explicit theoretical characterisation demanded by his colleague. He appears equally fascinated by such disparate aesthetic achievements as the dense fictions of Proust, the kitsch lithographs and engravings of Grandville, the remarkable Parisian photographs of Atget, the transcendentalist art of Klee and the popular films of Chaplin.

Despite their differences, however, both men were outsiders. Zelnick refers to them as not Marxists but 'Marxians [who share] a modernist outlook and method, and champion artists who are modernists to the core - Benjamin, Baudelaire; Adorno, Schoenberg' (1985: 409). 
And both remained committed, after Marx, to salvaging hope in the face of fascism, armed conflict and dominant commodity capitalism. But only Benjamin conceived of the fláneur as potentially a part of this.

\section{Together and alone}

Bringing this debate forward into the present epoch requires understanding that Benjamin holds out some hope for a culture industry upon which Adorno mostly pours scorn. However, it is unfortunate that, in concert with cultural studies and post-structuralism embracing Benjamin for dislodging the 'halo' of modern art (Huyssen, 1984: 7), this basic truth has often led to an unsophisticated cordoning-off of Adorno as both elitist and passé. Both Adorno and Benjamin would, one suspects, be thoroughly disheartened by the general absence of political commitment associated with the even more profit-driven, more alienating, more omnipresent culture industries of the present age. For Adorno, these events would be most obviously signified by the infiltration of an all-pervasive commodity culture into a mostly marginalised, disorganised high art community. Benjamin in turn would be dismayed by the general absence of revelatory interpretations emanating from a mass media that has come to entirely dominate (and thus hugely constrain) the landscape of culture and aesthetics.

I stand convinced that neither Benjamin nor Adorno can survive being thrust into our present cultural epoch alone; Wolin is correct to contend that each requires the tempering influence of the other (1982: 210). Keeping the finely honed methodology of a perpetually suspicious Adorno side by side with the indistinctly articulated, sometimes equivocal approach of a tentatively hopeful Benjamin can lead to entirely new insights into what commonly is perceived as an unimpeachable intellectual division. Such an approach can also lead to a 
more structurally flexible theory of culture and aesthetics, one capable of subverting stereotypical and oversimplified critical views of Adorno as stern elitist and Benjamin as tolerant radical respectively (Hansen, 1993: 27-28).

So far as Adorno is concerned, there has been no shortage of discussion on the limitations of his supposedly elitist approach to music in particular. Arguments are typically structured around one or more of the following concerns: that Adorno privileges contemplative engagements with the arts over other potential uses such as pleasure or distraction; that his requirement for true art to be esoteric excludes all but a small few of the population from the possibility of being transformed through its emancipative qualities; that his examples of worthwhile culture are wholly Eurocentric and therefore highly restrictive; that he is blind to analogous modernist-style progressions occurring beyond the world of traditional art music in particular; that he steadfastly accuses the popular art forms of the 20th-century, such as pop and rock music and film, of capitulating to the forces of capitalism, when in truth these are sometimes sites of subversion and discernment. ${ }^{8}$ And to these one might add the suggestion that over the course of a long career of writing on culture and aesthetics generally, inconsistencies sometimes surface in ways that compromise his ostensibly unyielding position on mass-produced art. For example, one can contrast Adorno's positive reference to 'the incomparable cinematic farces of the Marx Brothers' in 'The Relationship of Philosophy and Music' (2002: 136) with the following statement from Minima Moralia: 'Every visit to the cinema leaves me, against all my vigilance, stupider and worse' $(1974: 25){ }^{9}$

Benjamin's vision is perhaps less easily pared down to an orderly list of criticisms. His belief in both the fading of art's traditional aura and the unlikelihood of progress, as associated with the enterprise of modernism, opens the door to all manner of untapped possibilities; rather 
than hindering analysis, Benjamin's own inconsistencies often neatly reflect the greater ambiguity of his life's work. He conceived of the Arcades project not as a top-down assessment of modernity, but instead as one involving 'those minutiae of everyday collective practices and experiences that - in spite of their overall fetishistic nature - contain a spark of radical energies' (Markus, 2006: 87). As such, he pursues a utopian vision which translates not just to a select few intellectuals.

In contrast to the latter-day reception of Adorno, Benjamin's integration into postmodern thought has been relatively smooth: the majority of critics now consider his philosophical approach the more productive of the two (McRobbie, 2005: 303; Markus, 2006: 68). But if in retrospect it can be argued that Adorno was overly optimistic as to the revolutionary potential of high modernism, might Benjamin have gone too far in his disavowal of the ritual value of high art? As Benjamin's vision simultaneously becomes both more palatable to modern-day scholars and more prophetic of global capitalism and commodity fetishism, it is unsurprising that it is Adorno himself who becomes his most important critic:

The condemnation of aura easily becomes the dismissal of qualitatively modern art that distances itself from the logic of familiar things; the critique of aura thereby cloaks the products of mass culture in which profit is hidden and whose trace they bear ... the failure of Benjamin's grandly conceived theory of reproduction remains that its bipolar categories make it impossible to distinguish between a conception of art that is free of ideology to its core and the misuse of aesthetic rationality for mass exploitation and mass domination, a possibility he hardly touches upon. (Adorno, 1997: 56)

Benjamin, then, is willing to admire the achievements of high modernism, but only from that precise position where his view of its alternative in modernity - mass culture - can also be 
apprehended and absorbed. He cannot quite bring himself to turn away from the spectacle of the culture of the majority, convinced that from amongst the detritus positive elements will emerge (McRobbie, 2005: 312). Like the cow in Wassily Kandinsky's famous painting of 1910, he lingers on the cusp of a pure non-representational aesthetic, merged into his surroundings yet still partially visible. Because he is not concerned with linear reasoning, for Benjamin modernism does not come down to a simple movement from representation to abstraction, tonality to atonality, and so forth. More likely, he sees in modernism a volatile combination of sophistication, disintegration and crisis. But this does not mean that Benjamin stands in direct opposition to Adorno. Believing that absolute hope lies in neither a rarefied modernism nor a troubled mass culture, he marshals his thoughts while moving comfortably, flâneur-like, from Proust to Grandville, Atget to Klee. Benjamin, for whom any hope is always mitigated by 'intellectual sadness [and] despair' (McRobbie, 2005: 297), less expects than allows for the possibility of revolutionary praxis in the culture and art of the mainstream. For this reason, it can be argued that many have too-easily linked Benjamin with the critical evolution whereby popular texts are considered 'the privileged sites of ideology' (McRobbie, 2005: 297) and an 'old hierarchy [is] simply reversed' (Huyssen, 2002: 52).

Ultimately, the seemingly diametrical positions of Benjamin and Adorno vis-à-vis art and culture serve to explain why they should be brought forward into the new millennium in a reciprocal fashion. It has been contended that their respective overestimations of the possibilities inherent in mass culture and modernism lead to 'signs of imminent conservatism' (Aesthetics and Politics ['Presentation III'] 2007, 107). While it is necessary to acknowledge that neither could have foreseen the 'extremely complex and variegated set of dialectical relationships between "high" and "low" and "avant-garde" and "popular"" (108) in the present era, it is nonetheless the case that both tended to downplay specific historical 
attributes in aesthetics - Adorno, use value; Benjamin, eternal value - that might more usefully be merged than held in opposition.

Thus the contrasting stances of Adorno and Benjamin can be seen as complementary, not competing, philosophies on art and culture. In the case of Adorno, his modernist logic is vital primarily because it tempers the stultifying omnipresence of commodity culture with the (often neglected) radical possibilities of experimentation, dissonance and negation. He serves as a reminder - in the face of both a chaotic postmodernism and an unimaginative antimodernism - of art's ability to question and transcend the widespread banality of the mass media. Adorno also reminds us of the need to ensure that debates concerning $21 \mathrm{st}-$ century culture do not stall in the cul-de-sac of populism, bypassing altogether esoteric or challenging aesthetic practices. Considered today Adorno is a means of preserving a little judicious distance between criticism and mass culture - his thinking (and this can hold true despite his theoretical blindness to non-affirmative forms of art) may function to moderate a situation where the salience of mass culture leads to strategies that overemphasise its emancipatory promise.

Benjamin, on the other hand, offers mitigation in the face of consistent efforts to distance supposed high art from the everyday. He is available to soften the antinomy whereby, in Adorno's terms, it is thought that in the face of a materialist and deceptive popular culture modern art can only survive through recourse to its traditional values of authenticity and opacity. As such, through Benjamin it is possible to break away from the high-popular dichotomy without submitting to a culture industry rooted in distraction and self-indulgence; rather, his intrinsic ambiguity and fláneur-like wanderings offer both a link to and path away from Adornoesque negativity by way of exploring those aesthetic and cultural practices that 
take place at the fringes of contemporary culture. He restores the notion of historical development otherwise denied to that vast array of cultural endeavours not strictly aligned with the aesthetic values of modernism.

In my estimation, it is less helpful now to think of certain enlightened individuals as occupying such between-spaces. Instead, it is more important to comprehend how people can and often do bypass, or even defeat, an ever-present high-popular dichotomy by traversing in their own lives around the margins of their vast cultural world, operating, in the spirit of a modern-day flânerie, against the grain of a fully entrenched consumer culture.

\section{Flânerie in the 21st-century}

Another foretaste of a postmodern flânerie: one of the wondrous places Marco Polo describes in Italo Calvino's La Citta Invisibli (Invisible Cities) is Esmeralda, where travellers are faced with an infinite number of routes, via land or water, by which to reach their destination. After making a careful distinction between the manifest journeys of the everyday inhabitants and those of Esmeralda's clandestine population of cats, thieves, conspirators and illicit lovers, he concludes his account with the observation that:

a map of Esmeralda should include, marked in different coloured inks, all these routes, solid and liquid, evident and hidden. It is more difficult to fix on the map the routes of the swallows, who cut the air over the roofs, dropping long invisible parabolas with their still wings, darting to gulp a mosquito, spiralling upward, grazing a pinnacle, dominating from every point of their airy paths all the points of the city. (Calvino, 1997: 88)

Since Benjamin, there has been ambiguity both in what the flâneur might be doing and exactly where he - or, as can now be allowed, she (Wolff, 1989) - might be doing it. If there 
is a single aspect of the flâneur's character holds stable after Benjamin, it is probably his or her marginal aspect as one who resists the status quo of class politics within capitalism and remains existentially aware of a burgeoning modernity threatening to overwhelm at any moment (Patke, 2000: 12-13). As such, it is possible to imagine a virtually limitless range of characteristics of flânerie that might apply to circumstances where cultural interactions and interpretations go genuinely against the grain: texts, interpretations of specific texts, and interactions with a range of texts on the part of the individual that in some way trouble or confound mainstream expectations.

Ultimately, the spirit of flânerie suggested here is that of the individual drifting - much in the fashion of the swallow in Calvino's Esmeralda - through an immense cityscape of artefacts and detritus, finding loopholes and surviving at least in part outside of orthodox narratives. But the utopian character of this notion can be kept in check by constantly juxtaposing Benjamin with Adorno. In doing so, one encounters a moving dialectic - a constant interplay between the inevitable and the unexpected in modern life. The consciousness of latter-day flânerie thus balances somewhere on the cusp of hope and hopelessness, with the optimism that alternative routes do exist perpetually tempered by suspicion as to the iron grip of consumerism and the inexorable nature of multi-national capitalism. Such a consciousness is reflective of many aspects of the constantly shifting critical dialogue that took place between Benjamin and Adorno in the between-wars period.

It must be reiterated that the intention is not to revert to the idea of the flâneur as a special case amongst the crowd. To stray too far in this direction would be to imply that individuals outwit, as it were, the dominant consumer culture merely through their (distinctive) habits of consumption. In the foreword to The Practice of Everyday Life, Michel de Certeau dedicates 
his work to 'a common hero, a ubiquitous character, walking in countless thousands on the streets' (1984). The notion of flânerie I wish to evoke does embrace the concepts of 'making do' and 'being in-between' as described in Certeau. Taken on its own, however, Certeau's common hero eventually leads to a universal version of the flâneur who appears in Benjamin, one whose behaviour is intimately related to patterns of consumption. (Certeau refers at one point to 'the enigma of the consumer-sphinx' [31].) This is significant, as much of the work that followed in cultural studies shows that there is a fine line between negotiating a path through the minefield that is consumer culture and submitting, even if unintentionally, to what is effectively an uncritical endorsement of it. What is envisioned, rather, are lives played out in the between spaces, where individuals might loiter or else come and go in any direction: not the place of the poet who is 'the centre of an order of things of his own making' (Tester, 1994: 3), but simply a place where poetry might occur. Or, in other words, what is envisioned is not the flâneur but flânerie. ${ }^{10}$

A contemporary version of flânerie that can be considered part of each and every individual's potential repertoire of operating in today's society coincides, as Wiggerhaus so aptly puts it, with an attempt find 'in a time without dignity ... a trace of genuine dignity' (1994: 209). Even when one accepts the by now all-pervading nature of commodity culture, it is impossible to sustain an argument as to the compliance or rebelliousness of the individual without considering the entire range of their cultural engagements and on a persistent basis. The fláneur, as has already been allowed, relates closely to the example of the detective. ${ }^{11}$ The dialectical movement, sustained by this integrated reading of Adorno and Benjamin, is one from the poet and rarefied specimen to the everyday fláneur-detective with a potential awareness of mass culture's ability to crush them 'either physically or existentially' (Tester, 1994: 3-4). 
George Simmel believed that

the deepest problems of modern life derive from the claim of the individual to preserve the autonomy and individuality of his existence in the face of overwhelming social forces, of historical heritage, of external culture, and of the technique of life. (1997: 174-175)

Simmel's reference to modern life is most of all an evocation of the metropolis - that teeming mass of humanity and tremendous abundance of signs that, in this new century, with its bigger, more closely-connected cities (and so many more of them), with its ever-increasing technological sophistication (the internet has arguably created a single, colossal electronic cityscape), threatens to overcome independent action on behalf of the individual once and for all. It is at this precise location where Simmel's battle 'to preserve autonomy and individuality ... in the face of overwhelming social forces' $(1997,174-175)$ seems destined to carry on unabated. I concur with David Scobey when he says that the logic of modern-day flânerie is that of 'an act of consciousness - the drama of a solitary, peripatetic analyst moving through the cityscape and making sense of it' (1995, 337-338). The struggle of the individual in contemporary society is now played out, as Witkin reiterates (2000: 163), wholly within a media and cultural environment where everything is up for sale. No doubt the sheer dominance of the system dulls the search for many: the easy option is to follow the trails already laid out for us. So it can be granted that interpretive autonomy is likely to be greater amongst those who are neither (following Adorno) blindly accepting of the products of the culture industry nor (following Benjamin) eternally limited to the specificities of socalled elite culture. 
Yet while marginality and rebelliousness are vital to this conceptualisation of modern-day flânerie, it would be a mistake to assert that it is wholly reliant upon them. This would simply create another all-encompassing distinction, a third resting place for the cultural and aesthetic consciousness that opposes the traditional high and popular positions, without doing anything to unsettle or dismantle them. What is ultimately articulated in this model of flánerie are tactics for engaging with the labyrinthine culture of the 21 st-century that include those who might previously have been excluded, encourage optimism where there was once only despair, and promote scepticism where before there was a premature rejoicing.

\section{References}

Adorno, Theodor (1973) Negative Dialectics, trans. E. Ashton. New York: The Seabury Press.

Adorno, Theodor (1974) Minima Moralia: Reflections from Damaged Life, trans. E. Jephcott. London: New Left.

Adorno, Theodor (1997) Aesthetic Theory, trans. Robert Hullot-Kentor. Minneapolis: University of Minnesota Press.

Adorno, Theodor (2002) Essays on Music, Richard Leppert (ed.). Berkeley: University of California Press.

Adorno, Theodor, Benjamin, Walter, Bloch, Ernst, Brecht, Bertolt and Lukács Georg (2007) Aesthetics and Politics. London: Verso. 
Benjamin, Walter (1973) Illuminations, Hannah Arendt (ed.). London: Fontana.

Benjamin, Walter (1999) The Arcades Project, trans. Howard Eiland and Kevin McLaughlin. Cambridge: Harvard University Press.

Berman, Marshall (1983) All That is Solid Melts into Air: The Experience of Modernity. London: Verso.

Buck-Morss, Susan (1977) The Origin of Negative Dialectics: Theodor W. Adorno, Walter Benjamin and the Frankfurt Institute. Sussex: Harvester.

Buck-Morss, Susan (1989) The Dialectics of Seeing: Walter Benjamin and the Arcades Project. Cambridge: The MIT Press.

Bürger, Peter (1984) Theory of the Avant-Garde, trans. Michael Shaw. Manchester: Manchester University Press.

Calvino, Italo (1997) Invisible Cities, trans. William Weaver. London: Vintage.

Certeau Michel de (1984) The Practice of Everyday Life, trans. Steven Rendell. Berkeley: University of California Press.

Coetzee, J. M. (2001) ‘The Marvels of Walter Benjamin', New York Review of Books, 48(1): 28-33.

Donald, James (1999) Imagining the Modern City. London: The Athlone Press.

Donald, James (2005) 'Flannery', in Peter Brooker and Andrew Thacker (eds) Geographies of Modernism: Literatures, Cultures, Spaces. London: Routledge. 
Hansen, Miriam (1993) 'Of Mice and Ducks: Benjamin and Adorno on Disney', South Atlantic Quarterly, 92(1): 27-61.

Hegel, Georg (1977) Hegel's Phenomenology of Spirit, trans. A. Miller. Oxford: Oxford University Press.

Huyssen, Andreas (1984) 'Mapping the Postmodern’, New German Critique, 33: 5-52.

Huyssen, Andreas (2002) 'Adorno in Reverse: From Hollywood to Richard Wagner', in Nigel Gibson and Andrew Rubin (eds) Adorno: A Critical Reader. Oxford: Blackwell.

Jarvis, Simon (1998) Adorno: A Critical Introduction. Cambridge: Polity Press.

Kellner, Douglas (2002) 'Adorno and the Dialectics of Mass Culture', in Nigel Gibson and Andrew Rubin (eds) Adorno: a Critical Reader. Oxford: Blackwell.

McRobbie, Angela (2005) 'The Passegen-Werk and the Place of Walter Benjamin in Cultural Studies: Benjamin, Cultural Studies, Marxist Theories of Art', in Peter Osborne Walter Benjamin: Critical Evaluations in Cultural Theory. London: Routledge.

Marie, Laurent (2001) 'Jacques Tati's Play Time as New Babylon', in Mark Sheil and Tony Fitzmaurice (eds) Cinema and the City: Film and Urban Societies in a Global Context. London: Wiley-Blackwell.

Markus, György (2006) 'Adorno and Mass Culture: Autonomous Art Against the Culture Industry', Thesis Eleven, 86(1): 67-89. 
Paddison, Max (2004) Adorno, Modernism and Mass Culture: Essays on Critical Theory and Music. London: Kahn and Averill.

Patke, Rajeev (2000) 'Benjamin's Arcades Project and the Postcolonial City', Diacritics, 30(4): 3-14.

Scholem, Gershom and Adorno, Theodor (1994) The Correspondence of Walter Benjamin 1910-1940, trans. Manfred Jacobson and Evelyn Jacobson. Chicago: University of Chicago Press.

Scobey, David (1995) 'Commercial Culture, Urban Modernism, and the Intellectual Flâneur', American Quarterly, 47(2): 330-342.

Sennett, Richard (1990) The Conscience of the Eye: The Design and Social Life of Cities. New York: Alfred A. Knopf.

Simmel, Georg (1997) Simmel on Culture: Selected Writings, David Frisby and Mike Featherstone (eds). London: Sage.

Tester, Keith (1994) The Fláneur. London: Routledge.

Wiggerhaus, Rolf (1994) The Frankfurt School: Its History, Theories and Political Significance, trans. Michael Robertson. Cambridge: Polity Press.

Witkin, Robert (2000) ‘Why did Adorno 'Hate' Jazz?', Sociological Theory. 18/1: 145-170.

Wolff, Janet (1989). 'The Invisible Flâneuse: Women and the Literature of Modernity', in Andrew Benjamin (ed.) The Problems of Modernity: Adorno and Benjamin. London: Routledge.

Wolin, Richard (1982) Walter Benjamin: An Aesthetic of Redemption, New York: Columbia University Press. 
Zelnick, S. (1985) 'Marxism and Modernism: An Historical Study of Lukacs, Brecht, Benjamin and Adorno by Lunn, E' [Book review], Journal of Aesthetics and Art Criticism, 43(4): 408-409.

1 As Laurent Marie notes with reference to Playtime, Tati 'creates a kind of dynamic maze through which the spectator must wander. His or her gaze must acquire a nomadic quality so as to err freely in Tativille in search of new discoveries' (2001: 265). One could, of course, supplement this list of examples with more general scholarly investigations into the fate of the fláneur in contemporary society, such as in Keith Tester's The Fláneur (1994) and James Donald's Imagining the Modern City (1999).

2 This excerpt and the following (taken from Adorno's letter of reply dated 10 November) appear in The Correspondence of Walter Benjamin 1910-1940 (Scholem and Adorno).

${ }^{3}$ Coetzee (2001: 28): 'Benjamin was drawn to universities, remarked his friend Theodor Adorno, as Franz Kafka was drawn to insurance companies.'

${ }^{4}$ Aesthetics and Politics (Adorno et al., 2007) contains four unattributed presentations prepared by Livingston R, Anderson P and/or Mulhern F. All further citations will refer only to the title and number of presentation when appropriate.

${ }^{5}$ Elsewhere in the same correspondence, Adorno's exemplary sense of humour softens objections to Benjamin's methodology and clarifies his admiration for what the latter is attempting to achieve: 'Do not fear that I am making use of this opportunity to mount my hobbyhorse. I will content myself with handing it a lump of sugar en passant and for the rest will try to indicate to you the theoretical basis of my aversion to this particular type of concreteness and its behaviouristic features' (p. 581).

${ }^{6}$ A point Jameson corroborates (in the afterword to Adorno et al., 2007) when he speaks of 'the full force and constriction of that stark alternative between a mass audience or media culture, and a minority 'elite' modernism, in which our thinking about aesthetics today is inevitably locked' (p. 207).

${ }^{7}$ The link between Hegel and Benjamin can be identified, as Wolin suggests, in the introduction to the former's Phenomenology of Spirit, where one encounters such phrases as 'useless ideas and locutions about cognition as an instrument for getting hold of the absolute' and '[the] empty appearance of knowing' (1977: 48).

${ }^{8}$ For an excellent and even-handed summary of criticisms of Adorno, see Paddison (2004: 81-105).

${ }^{9}$ As György Markus presciently argues: '[Adorno] is a truly significant thinker, because he is deadly consistent in his inconsistencies' (2006: 79). 
${ }^{10}$ Thus when James Donald asks, in his discussion on contemporary flánerie (or, as he terms it, 'flannery'), 'what might this exercise of freedom [to navigate modernity] look like?' (2005: 163), I argue that here such a question is misconceived. Envisaged by way of an ongoing dialogue between Benjamin and Adorno, flánerie in my conception is everywhere yet nowhere: an exhilarating but imposing vista of infinite aesthetic and cultural possibilities which remain just that - possibilities. The emancipatory potential of flánerie would therefore be compromised by any attempt to pin down individual examples of this navigational practice - it is, following Adorno, not the resolution of an argument but rather a pathway to perpetual critique.

${ }^{11}$ Indeed, for Benjamin, 'performed in the figure of the fláneur is that of the detective' (1999: 442). 